\title{
Spectres of Nature in the Trail Building Assemblage
}

\section{Jim Cherrington ${ }^{1}$ (D) J Jack Black ${ }^{1}$}

Received: 2 July 2019 / Accepted: 22 September 2019/Published online: 26 October 2019

(C) The Author(s) 2019

\begin{abstract}
Through research that was conducted with mountain bike trail builders, this article explores the processes by which socio-natures or 'emergent ecologies' are formed through the assemblage of trail building, mountain bike riding and matter. In moving conversations about 'Nature' beyond essentialist readings and dualistic thinking, we consider how ecological sensibilities are reflected in the complex, lived realities of the trail building community. Specifically, we draw on Morton's (2017) notion of the 'symbiotic real' to examine how participants connect with a range of objects and non-humans, revealing a 'spectral' existence in which they take pleasure in building material features that are only partially of their creation. Such 'tuning' to the symbiotic real was manifest in the ongoing battle that the trail builders maintained with water. This battle not only emphasized the fragility of their trail construction but also the temporal significance of the environments that these creations were rendered in/with. In conclusion, we argue that these findings present an ecological awareness that views nature as neither static, inert or fixed, but instead, as a temporal 'nowness', formed from the ambiguity of being in and with nature. Ecologically, this provides a unique form of orientation that re-establishes the ambiguity between humans and nature, without privileging the former. It is set against this ecological (un)awareness that we believe a re-orientation can be made to our understandings of leisure, the Anthropocene and the nature-culture dyad.
\end{abstract}

Keywords Mountain biking $\cdot$ Trail building $\cdot$ New materialism $\cdot$ Nature $\cdot$ Symbiotic real . Anthropocene

Jim Cherrington

j.cherrington@shu.ac.uk

Jack Black

j.black@shu.ac.uk

1 Collegiate Crescent Faculty of Health and Wellbeing, Sheffield Hallam University, A225,

Collegiate Hall, Sheffield S10 2BP, UK 


\section{Introduction}

Following a series of seismic changes throughout the nineteenth century, prompted by emergence of what Morton (2016: 42) describes as an 'agrilogistic' world logic - the imperative to redefine and re-think nature-society relations has developed a renewed urgency as scholars from a range of disciplines have begun to recognize the significance of the Anthropocene as a socio-ecological phenomenon in which the objects of 'nature' and culture are synonymic (Moore 2015; Dalby 2013; Wark 2015a). As Purdy (2015: 2-3) elucidates:

Because we shape everything, from the upper atmosphere to the deep seas, there is no more nature that stands apart from human beings. There is no place or living thing that we [humans] haven't changed. Our mark is on the cycle of weather and seasons, the global map of bioregions, and the DNA that organises matter into life. It makes no sense now to honour and preserve a nature that is defined by being not human.

Indeed, the consequences of living in the Anthropocene are profound and far-reaching, and not confined only to the emerging rift in the nature-culture dyad. Questions of agency (both human and non-human), space, time, and ethics abound. To paraphrase Morton (2013), in a global world, entities, and by extension experiences, have become entangled with so many other phenomena that they are increasingly defined by nonlocal relationships, infinite temporalities and interobjective affects; affects which, because of their magnitude are increasingly difficult to perceive in human terms and can only be mediated through a 'shared sensual space' (2013:86).

Despite the sense of urgency with which these issues have been addressed within the humanities and natural sciences, scholars dedicated to addressing the relationship between leisure and society have been slow to respond to this emerging agenda (Mansfield 2009). This is somewhat surprising given leisure's unique relationship with the 'natural' environment as well as the manifold threats that such activities may pose with regard to resource depletion, pollution, land-use degradation and habitat loss (Mansfield and Wheaton 2011). Where literature has adopted this focus, the very notion of 'nature' has been left largely unproblematised, and scholars have been criticized for simply 'greening' pre-existing theories in a manner 'closely approximating the theoretical traditions of the discipline as a whole, albeit with an eco-prefix added on' (Stevens 2012:580). This has led to calls for less anthropocentric (Dashper 2019; Weedon 2015) and more sustained 'ecocentric' (Brymer 2009) analyses of leisure activity in which human and nonhuman agency is taken more seriously into consideration.

As a useful counterweight to this, Kopnina et al. (2018) discern at least three different targets for ecocentric critique that might be usefully adopted when analysing the nature-leisure nexus, including 'industriocentrism', the belief in production as the key to human development; 'human chauvinism', giving preference to humans over non-humans; and, 'speciesism', the assumption that humans are biologically, ethically and socially superior to other species. In doing so, she reminds us that:

questioning anthropocentrism is far more than an academic exercise of debating the dominant cultural motif of placing humans at the centre of material and ethical concerns. It is a fertile way of shifting the focus of attention away from the problem symptoms of our time (Kopnina 2014: 387). 
Following Kopnina (2014:388), one might therefore ask: 'what does it mean to position Anthropos in the centre?', and, by extension, what issues need to be addressed within the sociology of leisure to bring the relationship between nature, culture and the biosphere into sharper focus? In part, this entails a greater emphasis on matter and the way that such matter, including that which has typically been confined to both the 'natural' (i.e. trees, rocks, dirt, mountains) and the artificial (i.e. bikes, spades, pick axes), becomes 'enrolled' (Latour 1999) in human activity.

Accounting for this process of enrolment involves a consideration of the way in which the world and the connections within it are produced by a range of material forces (Braidotti 2013). In addition, it requires an ontological leap in which matter is conceived not as static, inert or 'fixed' in meaning, nor a mere backdrop for human agents, but rather as entangled phenomena whose meanings develop through their emergent, immanent relationality (Monforte 2018: 4). For Snaza et al. (2016), this has enormous implications for critiques of anthropocentrism. In fact, when matter is considered at the centre of human activity 'there is no longer a knowing (human) subject who acts and a passive (nonhuman) object that is acted upon: everything is entangled' (Snaza et al. 2016: xvii). Accordingly, analysing the nature-culture dyad from the perspective of New Materialism 'adds an indispensable understanding of anthropocentrism's upshot: The self-placement of Man at the Center has disallowed a vantage point from which any need or desire for limiting human expansionism might be discerned' (Kopnina 2014: 390).

With these debates in mind, this paper draws on interviews with 20 mountain bike trail builders in England to explore the process by which socio-natures or 'emergent ecologies' (Rocheleau and Roth 2007) are formed through the assemblages of trail building, mountain bike riding and the materials that trail builders encounter in their labour. By (re)focusing on the 'intimate and divergent relations between bodies, objects, orders and spaces', we reveal how the trails' construction forms an 'emergent property' between the human and non-human (Marston et al. 2005: 425). Leaning on a growing body of theory associated with New Materialism and Object-Oriented Ontology (OOO), we hope to move conversations about leisure in 'Nature' beyond essentialist readings and dualistic thinking, towards a consideration of praxis that better reflects the complex, lived realities of the the anthropocene.

\section{Nature-Based Leisure}

To date, much work dedicated to the study of leisure and the environment can be located within a realist or idealist paradigm (White et al. 2016). Here, nature is concieved as being either independent from humans (realist) or closely aligned with a Malthusian (idealist) focus on the malignant features of the human condition (i.e. death, war, poverty, over-production of food). In scholarly accounts concerned with 'green exercise' (Pretty et al. 2007), for instance, nature is said to be beneficial when it is 'directly experienced' by (human) exercisers, that is, when people make a positive decision to go to places where there is green nature. Equally important, according to these researchers, is the 'incidental' physical activity whereupon exercise is secondary to other motives, such as commuting via bicycle through woodland environments or raising ones heartrate through gardening (Thompson 2018). In addition, Coon et al. (2011) describe the mental 
health benefits that can be accrued through one's exposure to views of nature, whilst Yeh et al. (2016) analyse the supposedly synergistic relationships between emotional wellbeing and 'green' physical activity. Studies couched in similar terms have also espoused the social benefits of such activity, citing improvements in, amongst other things social capital, educational attainment/school attendance, and enhanced selfesteem following family bereavement (Brewer and Sparkes 2011). In many such studies, the claims made in support of green exercise are framed by neo-liberal ideologies concerned with reducing the financial burden of sedentary (in)activity/mental health whilst encouraging individuals to take responsibility for their own health and wellbeing (Mansfield 2018). The emphasis is therefore on nature as an 'inanimate resource that can be harvested through human activities; used as a 'playground for natural highs' (Brymer and Gray 2009: 136).

However, in recent years there have been a number of constructivist and posthuman/ new materialist challenges to these assumptions. These challenged have been levelled on the grounds that both realist and idealist approaches have a tendency to reduce nature to a static unchanging object that can be picked at analytically. For White et al. (2016), these criticisms can be grouped into three distinctive areas. First, there is the 'view from nowhere' (ibid: 9), in which discussions about dominant (and changing) values and attitudes towards nature are absent. This is a critical oversight when one considers, for example, the historical variations in perception, from the notion of nature as god, through to nature as an ideal and subsequently the period of romanticism that interpreted nature as salvation from society. Second, we are left with no way of accounting for the sense of relativism inherent in the leisure experience, as individuals are seen to adhere to a universal metanarrative that informs and conditions any and all experience. Finally, debates around the real or ideal qualities of nature tend towards dogmatic form of anthropocentrism, whereby, in the context of leisure, nature is positionned as inanimate, 'providing a resource, medium or place for human action, an obstacle for conquering, or a playground for exhilaration' (Brymer and Gray 2009: 135-136).

In recognizing the need for more focussed attention on the leisure-nature nexus, Mansfield and Wheaton (2011) highlight the absence of explicit discussions regarding the importance and complexity of environmental politics in leisure studies. In addressing this lacuna, they bring attention to the continued (and growing) environmental threat posed by the increasing popularity and commodification of sport, leisure and tourism. Within this expansive and diverse special issue, in which the focus is predominantly on the political consequences of environment use and degradation, scholars cover a multitude of issues from the complexity of inland water use by kayakers in Wales (UK) (Church and Ravenscroft 2011) to the historically fractious relationship between 'noisy sports' (such as power-boating and off-road motoring) and other users in the Lake District National Park (UK) (Collins 2011). In addition to these investigations is the experiental and phenomenological experiences from which new nature relations might emerge (Humberstone 2011).

Notably, Leledaki and Collinson (2015) convincingly illustrate how outdoor recration can encourage environmentalist sensibilities that contain scope for both individual and political transformation, and/or different ways of 'feeling', as with the disabled and ethnic minority communities who took part in the Mentro Allen community programme in Wales (UK). What such accounts therefore illustrate is the complex 
and often contradictory way in which notions of 'nature' and the 'environment' are evoked in late-capitalist societies, and the need to address the overlapping micro, meso and macro interpretations that may exist within the varying contexts of nature-based leisure.

More importantly, this emerging field regarding the political ecology of leisure has raised some important questions regarding the sport/leisure-nature nexus, and has led the way in inspiring a new generation of leisure scholars to dedicate more critical attention to the importance of leisure as both a discursive and material vehicle through which nature is experienced. It has also instigated inter/trans disciplinary dialogue between leisure studies and other related subjects such as the the environmental sciences and geography. Yet much of the literature still fosters elements of what Naes (1972) calls a 'shallow ecology movement', which set about fighting pollution and resource depletion inorder to improve, or further sustain, the health and wellbeing of people in developed countries, and focusses almost exlusively on the human components of these initiatives. Furthermore, notwithstanding recent commentaries by the likes of Markula (2018) and Fullagar (2017), the sociology of leisure appears to mirror the sluggish development of an environmental sociology more generally. In its rush to denounce the anthropocentric bias of orthodox accounts, commentators have neglected to deal with fundamental questions regarding agency, ethics and identity in these new nature-cultures, and the way in which such issues might be manifest in the activities and motivations of their participants. As a result, questions about specific manifestations of anti-anthropocentric praxis, as well as the viability of these alternatives, remain at best under-analysed or, at worst, completely ignored.

\subsection{Ecological Assemblages: a View on Fragility on Instability in Leisure}

In furthering our understanding of the densely entangled nature of human and material life, Bennett (2010) argues that matter can have its own vibrancy; that is, 'it' pulses with life. Her central assertion is that things are not simply alive in a protean or elemental way, but that nonhuman matter can have the ability to produce effects that are both 'dramatic and subtle' (Bennett 2010: 6). These 'actants', which can be human or nonhuman, share the same agentic capacity, in that they can 'do things' with 'sufficient coherence to make a difference, produce effects, [and] alter the course of events' (Bennett 2010: viii). This is not to say, as critics of this idea might speculate, that matter has the gift of consciousness, or the ability to reflect upon its own mortality, but rather, that there exists complex relations between human behaviour and a range of nonhuman processes with varying degrees of agency (Connolly 2013).

Understanding the implications of this mutual and fragile (inter)dependence within leisure therefore requires a radical recasting of agency and structure that is better placed to explain the heterogeneous networks between human and nonhumans. For Bennett (2010: 31), such a shift in thinking calls for a more distributive agency which 'does not posit the subject as the root cause of an effect'. That is, rather than seeing agency as an ability to think in a moral capacity linked with 'advance plan or an intention' (Bennett 2010: 31), Bennett argues that agency should be seen as comprising an 'ecological assemblage' (Bennett 2010: 97), defined by a series of interconnected parts that are permanently in-flux, owing to their loose and fragile configurations. These multiple materialities can include - but are not limited to - human bodies, other animate life 
forms, objects, spaces, places and the natural and built environment, as well as material forces such as gravity and time (Fox and Alldred 2018). Accordingly, many scholars have described this dynamic agentic assemblage as an 'immanent ontology' (Braun 2015:2). This levels taken for granted dualisms in orthodox sociological and environmental thought such as, human-inhuman, organic-inorganic, local-global by revealing an 'endless cascade of events comprising the material effects of both nature and culture, that together produce the world and human history' (Fox and Alldred 2018: 4).

These human and non-human assemblages are most evident in the relationships between mountain bike riders and landscapes, as noted in the work of Brown (2012; 2014; Brown et al. 2008). Brown contends that mountain biking is characterized by a range of material exchanges that effect the participants' levels of enjoyment in both a negative and positive manner. When there is synergy between the rider and landscape, the assemblage is hidden, their bodies are 'absent' (Leder 1990) and the allure of mastery is maintained. Individuals become 'attuned to the 'feel' of granularity, gradient and micro-to-macro topographies of the landscape' (Brown 2014: 26) and the emotional reaction is therefore a pleasurable one. However, from time to time certain 'mediating' (Latour 2005) features such as roots, rocks or mud, may throw the riders off course, resulting in a crash or an injury. Subsequently, riders re-immerse themselves in the material landscape and reflexively monitor their embodied connection, in order to facilitate skill acquisition (Taylor 2009).

Equally interesting is the way that the sense of connection between bike and surface may facilitate a heightened sense of risk, as participants become further aware of the instability of the human-non human assemblage (Creyer et al. 2003; Heer et al. 2003). Crucial in such instances is the way in which the nonhuman "not only disciplines in the "negative" sense, but it also enables ... and crucially, it promises' (Michael 2000:42). Indeed, the vibrant exchanges between humans and matter not only effect the human participants, but have an impact on the mountain bike trails themselves, as the physical impact of bikes and the routes chosen by the riders alter their material and aesthetic constitution' (Gibbs and Holloway 2018).

A key aspect of these assemblages is their fragile and unstable attachments. For instance, Harvey (2014) argue that seeing nonhumans as part of assemblages requires us to recognize the instability of these relationships, as well as the constant care and attention that is required by humans to build and maintain the allure of stability. In the case of nature sport, Cherrington et al. (2018) describe how the organizers of the Marathon des Sables - a prominent ultramarathon event - conceal a contradictory orientation with nature, inherent in the event's reliance on marketing and technology, by reinforcing an ideological vision that promises the runners an unspoilt, primitive wilderness. Yet, where society and matter exchange properties, there is always a blind spot in these interactions (Latour 1993), which reveal the very real possibility for the assemblage to be disrupted. As Harman (2012: 191) posits when describing the ontology of objects:

If all objects were completely determined by the structure or context in which they resided, there is no reason why anything would ever change, since a thing would be nothing more that its current context. For any change to be possible, objects must be an excess or surplus outside their current range of relations, vulnerable to some of those relations but insensible to others 
Morton (2017) describes this process as object withdrawal, which is the manner in which no experience or interpretation can totally consume a given entity; they are always subject to a rule of ' $1+n$ ' (2017: 82). Wholes, therefore, are not greater than the sum of their parts, but are rather subscended by them, which means that 'parts are not just mechanical components of wholes, and that there can be genuine surprise and novelty in the world' (Morton 2017: 102). Instead of acknowledging this strangeness, Morton (2017) contends that environmentalism turn wholes (horses, the sea, mountains etc.) into things that are radically different from us, and as a consequence do exactly what they claim not to do: 'universalise the human by distinguishing human beings metaphysically from all non-humans ... a move that seriously weakens, unconsciously, its political edge' (2017: 39). However, in recognizing that things are always subscended by their parts, Morton offers us a way of thinking about mountain biking in which participation is neither reducible to a whole (i.e. as taking place in 'Nature') or its constituent features (individual's 'Nature' connection), but rather, as an ecological reality that is already given in the 'symbiotic real' (2017: 25). It is to this aspect of Morton's work that we shall now turn.

\subsection{Acknowledging our Ecological Ambiguity: Symbiotic Real, Dark Ecology and the Spectrality of Being}

Object-orientated ontology (OOO) is a term coined by Graham Harman, and is characterized by a theoretical commitment to thinking about objects beyond the real of human experience (Lemke 2017). Though typically loose in their associations, object-oriented ontologists are united in their objection to Kantian correlationism, which holds that objects can only be understood through human access to them or rather, the correlation between (human) thought and being. According to Harman (2012), this form of correlationism, which has dogged Western philosophy since the eighteenth century, is manifest in 3 different ways. In the first instance, scholars are guilty of undermining objects, or reducing such objects to a definitive essence which is no more than the sum of its parts. Secondly, and in a manner characteristic of much work within the social, cultural and historical study of nature-based recreation (see above), analyses can be accused of overmining objects. This reflects a process whereby what we call a thing is 'nothing in its own right, but only a functional table-effect for someone or... for other entities' (Harman 2012:18). Finally, Harman levels a critique at New Materialist analyses for their inherent tendency towards 'duomining' - a combination of 'undermining' and 'overmining' in which things are reduced to essences via human intentions. Thus, in Harman's (2016: 27-28) words:

If we reduce an object downward to its pieces, we cannot explain emergence; if we reduce it to its effects, we cannot explain change. From here it is easy to see why we need the thing-in-itself as the reality cannot be converted into either of the two basic forms of knowledge: what is a thing made of, what a thing does

By way of contrast, Harman suggests a radically different view of objects that centres on two principle claims: (1) that individual entities of various sizes and scales exist in their own right, beyond human correlation; and, correspondingly, (2) that these objects are never exhausted (or made permanent) by their relations (Campbell et al. 2019). A 
rock for instance, might mean many things to different trail builders - it can be a hazard, an object of beauty, an obstacle to build into a technically challenging feature, or a way of marking the edge of a trail, but the rock is still a rock. It still has certain 'objective' qualities, such as its weight or texture that appear as universal features of its ontological composition. According to Morton (2017), it is through this process of withdrawal that our conception of 'nature' (or what he terms the 'symbiotic real') emerges, as it is through this infinitely regressive process that an entity such as nature is outscaled by its parts (i.e birds, bees, soil, grass etc.). Hence, 'however absurd and amazing it sounds, we need to say "the whole is always smaller than the sum of it's parts"'(Morton 2017:106). Objects, and by extention 'nature' is always speculative, 'weird' (Morton 2017) or 'uncanny' (Morton 2016); it incessantly surprises and permanently escapes human interpretation, and it is this wierdness that should be embraced in realizing the 'mysterious depths and the marvellous plurality of concrete objects' (Harman 2009: 156).

In object-oriented ontology, and specifically the work of Morton humans (and by extention leisure) are therefore indelibly bound with nature and non-human things in such a way that their separation has never existed and that the two are (inter)dependently affected (Morton 2007, 2017, 2018). Morton (2017, 2018) approaches this relationship via his notion of the symbiotic real. The symbiotic real refers to humans' relationship with/in the biosphere, denoting a solidarity between human and non-human so that 'Human means me plus my nonhuman prostheses and symbionts, such as my bacterial microbiome and my technological gadgets, an entity that cannot be determined in advance within a thin, rigid outline or rigidly demarcated from the symbiotic real' (Morton 2017: 40). Like Harman, Morton uses this notion to contest Kantian correlationism and to redirect our attention to how certain framings of Nature work to separate the 'human' from the non-human. As a result, what we call 'Nature is a way to sever oneself from the strangeness of the symbiotic real', that is, the sense of solidarity that exists between human and non-human beings.

The significance of Morton's approach is that, for him, it is relatively easy to reorientate ourselves to this form of ecological thought. Primarily, this resides upon dissolving any fixed separation between the human and non-human, between 'inside' and 'outside'. Much like his reference to the bacteria which constitutes our microbiome, we:

are already a symbiotic being entangled with other symbiotic beings. The problem with ecological awareness and action isn't that it's horribly difficult. It's that it's too easy. You are breathing air, your bacterial microbiome is humming away, evolution is silently unfolding in the background. Somewhere, a bird is singing and clouds pass overhead. ... You don't have to be ecological. Because you are ecological (Morton 2018: 215 [italics in original]).

Therefore, while the symbiotic real emphasizes the interconnections between the human and non-human, it does not reduce either the human or non-human to these relations. Rather, while drawing attention to the ambiguity which an understanding of the symbiotic real prescribes, Morton paradoxically emphasizes how an 'Ecological awareness gives you a world in which everything is relevant to everything else, but is also really unique and vivid and distinct at the very same time' (Morton 2018: 88). 
Such awareness is considered further in Morton's 'dark ecology', which serves to bring together the sense of sudden ambiguity that encompasses an ecological approach that neither overlooks or disregards our symbiotic entanglement. Notably, Morton (2016) clarifies this approach with the assertion that:

Melancholy is irreducible because it's ecological; there is no way out of abjection because of symbiosis and interdependence. To exist is to coexist. Yet this coexistence is suffused with pleasure, pleasure that appears perverse from the standpoint of the subject under the illusion that it has stripped the abjection from itself (2016: 129)

Indeed, these 'dark' and evanescent characteristics are grounded in the partiality (the object's withdrawal) that Morton's object-oriented ontology promotes as well as the importance of proposing an outlook that privileges a non-hierarchical account of being: interbeing. This sense of interbeing - a connection between human and non-human - is reflected in Morton's desire to highlight the spectrality of being. That is, for Morton (2017), such 'Ecological awareness is saturated with nothingness, a shimmering or flickering, a shadow play of presence and absence intertwined' (2017: 78 [italics in original]). This presence and absence reflects a 'haunting' that, paradoxically, reestablishes the relationship between presence and absence. In this sense, it is not the case that human waste, once thrown away, simply vanishes and disappears from our immediate purview, but rather, human waste is decidedly spectral, remaining with us, haunting us from somewhere else. This spectrality extenuates the ambiguity of being and our need to live with, accept and relate to such ambiguity. In the context of leisure, this provides a unique form of orientation that re-establishes the ambiguity between humans and nature, without privileging the former.

The following sections will aim to examine this ambivalence in interviews conducted with mountain bike trail builders. In view of Morton's symbiotic real, dark ecology and spectrality of being, attention will be afforded to exploring how narratives of 'Nature' emerged out of, what we refer to as, the trail building assemblage. In so doing, we seek to unpack and understand the extent to which trail building can help 'tune' (Morton 2018: 108) the trail building community to the ambivalence and relative strangeness of an emergent ecological awareness.

\section{Situating Trail Builders within More-Than-Human Research}

This research project comprised 20 semi-structured interviews with mountain bike trail builders in England. The identities and motivations of the trail builders were dynamic and complex, and the type of building undertaken was dependent on a number of aspects, including their level of commitment; their perceived impact on and relationship with the landscapes in which they work; their own riding preferences; and, their adherence to English access laws. Despite these variances, the participants shared a common interest, that is, to make use of organic and/or inorganic materials to construct and maintain a rideable network of trails to suit a range of different interests and abilities. Of the 20 people that we interviewed, 14 were involved with a local advocacy group, three worked on behalf of a contractor or large organization such as the Forestry 
Commission and three worked independently on their own self-built projects, or to informally maintain an existing trail network. With regard to the former two groups, trails are being built on sites offically sanctionned by local authorities or private investors. By contrast, the third group's digging is regularly defined by its 'guerilla' like qualities, whereby participants are creating 'unmapped trails or obstacles ... alongside the formally sanctioned routes' (Gibbs and Holloway 2018:250) on land that is not lawfully their own.

Given variances in environmental law and access rights in the UK we decided to focus only on the experiences of trail builders in England, therefore ensuring that their expectations about digging, and by extension rights of access, were being 'invoked' in a similar way (Brown 2014). A combination of purposive and snowball sampling were used to recruit individuals to be interviewed. Purposive sampling was utilized as the lead researcher had existing contacts within the local area, allowing him to invite individuals to participate whose experiences were deemed appropriate to the topic (David and Sutton 2011). This was conducted via email and the strategic placement of promotional messages on the websites of national advocacy groups. Existing participants then acted as gatekeepers, referring people they thought were of interest. This proved particularly useful for recruiting participants whose trail building activities may be considered deviant or unlawful, as we found they were more likely to come forward having been recommended by a friend.

In both face-to-face and telephone interviews we encouraged each interviewee to talk openly about their interests and experiences, which encouraged a more organic response to their interpretation of 'Nature', trail building and mountain biking. Saldana (2011: 25) describes this as "an effective way of soliciting and documenting, in their own words, an 'individual's or group's perspectives, feelings, opinions, values, attitudes, and beliefs about their personal experiences and social world'. Thus, while there is a broad thrust to the direction of the questions, issues that arise from responses may give rise to new questions and directions of inquiry. Semi-stuctured interviews, therefore, allowed us to encourage a more open-ended conversational structure (Rubin and Rubin 2011) with the participants, establishing a level of rapport whilst remaining open to discussions that may on first impression, have seemed tangential to our initial objectives. Toma (2000) notes this as an important aspect between interviewer and interviewee as it helps participants to develop their own understandings as they respond. Such closeness, engagement, engagement and involvement can enhance the richness of the research, which was especially important given the personal, embodied and contentious connections between 'Nature' and trail building that we were hoping to ellicit.

Following the interviews, participant transcripts were subject to a thematic analysis. Here, our focus remained tied to what was said as opposed to how something was said, to whom, or for what purposes (Riessman 2008). To help supplement this approach and in order to not undermine our focus on the material and nonhuman aspects of the trail building assemblage, we drew on the analytic utility of Monforte, Perez-Samanieg and Smith's (2018) polyphonic approach to the study of culture, in which narrative and material orders of experience coalesce. Unlike orthodox narrative approaches which consider material environments as a mere backdrop for human interaction, we were keen to decouple the participants from an essential humanist subject and instead locate them within an assemblage of elements that exceeds the intentions of an individual 
narrator. In this vein, the notion of dialogue, once reserved for those forms of interaction that occur exclusively between people, is here extended to the exchanges between human and nonhuman, since a focus on matter necessitates a position in which agency is granted to anything which has a capacity to act and affect. The implication of this point of view is that the material is 'an active agent in the construction of discourse and reality' (Kuby 2017: 880), and that the individual cannot be isolated from the material $\leftrightarrow$ discursive embodied entanglements of a given social space. In addition, the relationship between landscape and trail builder is not one that is static or concrete, but one that is about a 'perpetually becoming-body in a dynamic relationship with its material environment' (Monforte et al. 2018: 3).

In light of the theoretical framework adopted in this study we therefore recognize the challengesand tensions that this type of method and analysis presents in unravelling a series of socio-material realities; what Panelli (2010) terms 'more than human' social geographies. Although a full account of these issues is beyond the scope of this paper (see Braun 2015 for a more comprehensive overview) there are two key implications of the New Materialist paradigm that we would like to highlight here. Firstly, in understanding the participant's responses as the product of an 'emergent, immanent relationality' (Monforte 2018: 3), we were keen to share our transcripts with the participants, encouraging them, where possible to comment on their narratives and contribute to their ongoing representation. In doing so, we were acknowledging both their ability to affect and their influence within the wider research-assemblage. Secondly, we appreciate that research can affect people in different ways, and accept, to paraphrase Latour (1996), that objects (of which we include research 'texts') always exceed their intentions. Thus, rather than portraying our participants as passive actors in a series of static 'environments' or 'settings', we have tried to develop a more dynamic form of data collection, analysis and dissemination that is alert to the affective flows (Fullagar 2017) that exist between various objects, experiences and states. Specifically, in a vein similar to Helle and Lyhne (2016) the interviewer-interviewee relationship engendered a reflexive sphere of communication. In what follows, we hope to present a representation of the trail builders emergent lifeworlds that is reflective of this process.

\section{Nature as Spectre}

Upon first inspection many of the participants appeared to adopt a romantic view of nature, in that trail building was described as a means of accessing remote, 'untouched' spaces that facilitated a sense of awe and wonder, specifically those that they associated with 'wild places' (Steve), 'biodiversity' (John), 'solitude' (Christine) and 'being outside' (Andy, Steve). Accordingly, individuals also described the way in which 'Nature' could be 'tasked' (Ingold 2000) in the interests of health and fitness (Howe and Morris 2009), skill acquisition/development (Krein 2014) and environmental conservation (Mansfield 2009). As John puts it when describing his motivations for digging: 'It's like an outdoor gym ... I think: "right, I've had a slovenly week, I've eaten too much... how much soil can I move around?"' These characteristics were often described in contrast to urban spaces, which participants felt lacked 'soul' and 'colour', as well as being too 'cleanly' and 'safe'. Thus, discursively at least, there is some evidence to suggest that the participants involvement in trail building is 
articulated through an anthropocentric perspective (Kopnina et al. 2018; ShoremanOuimet and Kopnina 2016), in which the human access mode is privileged above all others, and 'Nature's' resources are positioned for the benefit of human consumption. Furthermore, participants appear actively involved in attempts to demarcate a convenient ontological boundary between nature and culture, in which nature is positioned 'out there', beyond the confines of civilisation (Morton 2007).

These responses indicate a 'severing' (Morton 2017:13) of the connection between reality (the human correlated world) and the real (symbiosis of human and non-human entities), which was evident in Christine and Will's description of how they maintain the naturalness of a trail:

I generally look for a technical and a smooth side. If there is something that would put the average rider off then I will try to build a way around it. (Christine)

If you are maintaining a trail, trying to keep it natural, you're also trying to stop bikes from going too fast. To keep control you put corners in, not doing away with rocky sections, trying to keep speed down to something reasonable (Will)

Christine and Will's responses detail how different socio-natural configurations are invoked and enacted in different spaces (Macnaghten and Urry 1998), as well as determining who is and is not allowed to engage with them. In this case, the imaginary of the 'natural trail' is fixed through notions of speed and control, which are linked to normative (human) expectations about how to be in and move through various topographies (Brown 2014). For example, participants such as Will described how their digging activities were often curtailed by the expectations of the land manager, and/or pressure from other users groups, whose involvement in such 'Natural' spaces were perceived to be much more important than their own. In addition, by building trails to appeal to a wide range of abilities, Christine echoes wider policy concerns about equal access to the countryside, and the need to 'manage' rural spaces in order to widen participation (HMSO 2011). In sociological vernacular, this cultural shift is described as the neo-liberalization of nature, in which humans are interpellated by a series of micro, meso and macro transformations that turn environmental healths and harms into market concerns that are (tentatively) managed in line with the economy (Nelson 2014).

However, between this ideological view and the trail builders embodied practice, there exists a 'transcendental gap' (Morton 2018: 22), which reveals a more complicated and critical relationship with 'Nature'. That is, through the building of their mountain bike trails and investing their labour, the participants become increasingly 'withdrawn' from its essence (Morton 2017). This sense of withdrawal was not limited to human interactions, but extended to the relationships with non-human entities, which was most evident in conversations about the peculiarities of specific locations:

So where I am in my valley we have got a few different woods, but one in particular I've been working on in Autumn is very hard because the surface is shale over all the leaf mould that has fallen for years, all the organics. It's black, it's sludgy. Underneath that it's just clay. There are hardly any dry stone walls to repurpose - it's a tough place to build (Phil) 
I look at the landscape and just say 'what does this part of the hillside or this location offer? So, for example, in some parts of the woods that I build in it's really steep ... some parts are flat, so it's like 'how can we build more jumps and drop features in there?' So, I don't go in with an agenda, but I like to maximise the specific location that I'm using. (Andy)

In both excerpts, we learn of the way that matter is 'translated' (Latour 2005) within human-non-human assemblages, albeit with different affects. In the first instance, we see how nonhuman mediators such as weather, seasons, shale, leaves and clay, disrupt and intervene in the habitual relationship between Phil's body and the surrounding world (Michael 2001), resulting in tiredness and discomfort. As Bennett (2004) explains, this inertness and resistance to human appropriation is in and of itself a form of vitalism or 'thing-power'; for despite Phil's attempts to work and repurpose the landscape, dirt, shale and leaf mould refuse all attempts to be isolated abstracted and put to work in the service of human endeavours. In the second instance, and by contrast, we learn of the affordances provided by the woods and gradient of the landscape; matter is interpreted as being 'alive' and is said to contain creative potential. These affordances are not pre-given, but rather interpreted through an emergent socio-natural assemblage between trail builders, mountain bike riders and matter.

Of particular interest here is what many of the participants referred to as the process of 'vegging' up. Through this process, organic matter is placed behind a berm ${ }^{1}$ to encourage plants, trees and grasses to grow into the back of it. Over time, the lateral shoots and adventitious roots from these nonhumans form a rhizomatic pattern within the berm's structure, which improves its structural integrity. In this sense, the berm becomes a living adumbriation of Deleuze and Guattari's (1987) agencement. Deleuze and Guattari highlight how agencement materializes through two different processes: the coming together of human and nonhuman in symbiotic ways and the capacity of this symbiosis to 'affect'. In case of the former, the trail builders need to first learn how to be affected (Latour 2004). In other words, they have to 'be connected to the place you're in and have an affinity with it. Understand what the place feels like' (Will). Trail builders like Will learn how to tune themselves to the landscape and use local materials to encourage, amongst other things; 'flow' (Andy), 'challenge' (Steve) 'variety' (Paul) and 'sustainability' (Gary). The intersections between these various qualities results in what Lorimer (2008) terms 'nonhuman charisma'; the ability of nonhumans to take on such distinguishing qualities as to qualify for use by humans (in this case, mountain bikers). In recognition of this agencement, builders take a radical step; they extend the process of labour to include 'non-social labour' (Perkins 2008). That is, labour which includes biological processes such as root formation and weather erosion (see next section) as well as the energies and capacities invested by humans.

The upshot of this is that creativity is perceived less as individual, human accomplishment than an 'affective flow between assembled bodies, things and ideas' (Fox and Alldred 2017, p. 86). Furthermore, the creative products that

\footnotetext{
${ }^{1}$ A berm is a banked and curved feature on a trail that provides support for the rider as they move through a corner.
} 
these trail builders attempt to generate, including berms, tabletops, ${ }^{2}$ step downs ${ }^{3}$ and so on, can themselves produce affects, which are likely to exceed the builders' intentions (Latour 2005). To be a trail builder therefore demands a sense of connectedness between human and nonhuman organisms. This sense of connectedness is familiar, yet strange; it is 'strangely familiar' in that the features they build feel only partially of their creation (Morton 2013: 130). For trail builders it is not a matter of building wholes (environments). Instead, they are constantly humbled by the manner in which their creations and styles constantly exceeds their (individual) intentions (Morton 2017).

Such connectedness reflects Morton's (2017: 55) notion of the Spectre:

Specter could mean 'apparition', but it could also mean 'horrifying object', or it could mean 'illusion', or it could mean 'the shadow of a thing' ... In the specter, we encounter the ghostly presence of beings not yet formatted according to Nature, including the Nature in Marx: nonhumans subjected to human metabolism ... The more we think ecological beings - a human, a tree an ecosystem, a cloud - the more we find ourselves obliged to think them not as alive or dead, but spectral.

Here, the spectrality of nature was clearly displayed in accounts that noted how 'the odd fossil' (Conor) - something dead - could be found when digging as well as the smell of Wild Boar - something alive - could be smelt, but not seen, during a trail dig (Robert). Commenting specifically on the absent presence of Wild Boar, Robert explained:

I smell them long before I see them; I can tell when boar are within a 100 yards. You get that musky waft, because when they wallow they are essentially wallowing in their own toilet so you get that scent of manure. If there is a waft coming your way you know there is boar in the undergrowth probably watching you dig!

In these examples, the trail building assemblage represents a 'Human, psychic, social and philosophical being [that] resist[s] the severing of human and nonhuman sociality (Morton 2017:18). Whether reminding the builders of the past (finding fossils) or through the smelly presence of a Wild Boar, both examples revealed the spectral significance of an ecological sociality that effectively rendered an awareness of the human and non-human.

Notably, accounts of a 'human and nonhuman sociality' (Morton 2017) were also reflected in the following examples from Paul and Robert:

So, my favourite trail in the world is over in Slovenia in a place called beleaky paleni, which roughly translates as 'big mountain'. There is a cable car half way up the mountain that takes you to the top of the cliff and then a ski lift that takes

\footnotetext{
${ }^{2}$ A table top is a purpose-built mound of earth with a wide, flat top that can be jumped or rolled.

${ }^{3}$ A step down is a jump that has its landing lower than the take off. They can range dramatically in height, from 1 to $10 \mathrm{~m}$.
} 
you to the rest. Before all that was there and the trail that you then ride down is called Dolski Graben. ... it's not built for bikes, it was built for those goat herders 400, 800 years ago - I don't know exactly, but it's a long time - and it's just part of that mountain and it uses the shape of the mountain because they were all walking up and down with their cheeses to get back down the hill to sell them to market or whatever they were carrying back up. It didn't need to go straight up, it needed to twist and turn so that they could walk up it, and that is just brilliant. ... When you're out there on a natural trail then you're looking around to see what you can use from what nature has provided you with. ... That's sort of the style that I prefer and that trail in Slovenia has everything for me, but the biggest thing for me is that it is so engrained in that mountain's history that it doesn't feel like it's been built by machines and people specifically for bikes. (Paul)

... nature doesn't care that we continue on, it doesn't know we're there, it doesn't know we've built a track there. Some of it gets used as a shortcut by deer; they obviously know that there is a clearing through a section of wood and they're not daft. The wild boar use the new bridge over the road. They're not going to walk down the side and go down to the road, they've noticed there is a bridge there ... they just turn left and disappear into the undergrowth, because there's a damp spot where they like to wallow near the cycle centre. They take advantage of certain things. Like if we make a clearing or something like that they're not going to push their way through undergrowth if we've got a nice clearing. You can see from the amount of droppings from dear, rabbit, you name it. They like the trails. (Robert)

As evident in both accounts, a clear psychic and social relation emerged between the history of a particular mountain (Paul) and the animals that lived and used the trail sites (Robert). In each case, both men displayed a permanent attendance to the specific arrangements of the symbiotic real (Morton 2017), that, in the case of Paul, revealed a level of temporality that connected him to the history of the mountain and its former goat herders, and, in the case of Robert, to a nature that ambivalently acknowledged the track being built. It was only by tuning themselves to this sensibility that they could build trails that were fun, enjoyable and affective; and, more importantly, that were symbiotically part of the environment. The following section will consider this arrangement in closer detail, with particular attention given to the fragility of the trail building assemblage.

\subsection{Water, Erosion and Paranoia}

A related theme that emerged during the interviews was the material vibrancy that was attributed to water, with specific reference to the affect that it can have on the materialization of a rideable trail. Participants detailed the relentlessness of English rain, the ceaseless movement of water, and the time and effort that they had to invest in acquainting themselves with its properties. What was interesting in this respect was the way that Christine and Paul described water as being an inevitable, incontestable force: 
Water is going to go where it wants. You can persuade it to go somewhere some of the time but the rest of the time you have to accept that some of the trails do become a river in certain conditions ... Patience and persistence are important, but also thinking like the water and thinking how you are going to get it off the trail (Christine)

When you're looking at what sort of trail will work a lot of it comes down to water in this country. We're not in Utah or somewhere, we do have to be realistic that we are in a wet country ... It's important to understand what the ground is capable of and what you are going to have to do to make it useful as water can have a mind of its own (Paul)

A unifying theme that can be extrapoloated in these accounts is the uncompromising and uncontrollable qualities of water. In their study on the Sargasso Sea Alliance, Acton et al. (2019) point to the difficulty of attributing ownership over ocean spaces given their fluid, dynamic and divergent qualities. Similarly, Bakker (2004: 559) explores how water's spatiality and biophysical characteristics, as a 'life-giving, continually circulating, scale-linking resource' rub against the cold, calculating and de-sensitizing strategies adopted by market environmentalists, resisting commodification.

Managing erosion and maintaining trails is a key point of focus for the trail builders. Whilst some of the participants have been lucky enough to be involved in the construction of new trails, most were keen to challenge the stereotype of the 'perpetual trail generator' and 'creative genius' often represented in the media. Instead individuals emphasized the 'menial work' (Jason, Barry) or 'little tweaks' (Steve) that they attended to on a daily/weekly basis, which might include filling in holes and braking bumps, resurfacing trails with hardcore, re-sculpting berms and replacing rotting timber. In each of these instances, trail builders recognized the important role played by water. Resultantly, this relationship induced a physical and psychological state of paranoia:

We've built a berm and it's riding lovely and then it's like 'oh $\mathrm{s}^{* * t} \mathrm{t}$ we need a drain!' So, then you look at it and it's like 'right do we spend a day ripping that berm out and it never settles? For this reason I never stop thinking about the water. It gives me nightmares! (Barry)

The biggest thing we have learnt is how to manage water, which is impossible, but you have to try. You start at the top (of the trail) and you'll put a drain in, you go a bit further down and there's a puddle, so you put a drain in. So, what we tend to do is move the water about until we get it so that we're not riding through it. (Jason)

Morton (2017: 161) argues that the paranoia evidenced here is an important prerequisite for solidarity between humans and nonhumans, as in the despair that trail builders exhibit towards the water erosion we witness feelings of being 'haunted and watched' by an entity that is not their own. Elsewhere, this was also manifested in the builder's collective impulse to 'kick a drain' (i.e. remove pooling water with the kick of their heel) when they are riding their bikes, a compulsion that is often so overwhelming 
that it can prevent them from enjoying their ride. Yet the more they grappled with this sense of paranoia, the more the trail builders were humbled by the agency of nonhumans and their looming presence within the trail building assemblage, something that we have referred to elsewhere as 'dark ecology' Cherrington et al (2018). Indeed, it is through digging, kicking, and scraping - the physical connections between human and nonhuman - that this relationship is manifested.

Like the other nonhuman influences mentioned above, water was also seen to both extend and limit human capacities (Mirosa and Harris 2011). Some trail builders, for instance, described 'using' water to build technical features such as ruts and gulleys by deliberately encouraging it down the trail. Others such as Harry commented on how a torrential rain storm would wash the top soil from a freshly cut line, allowing him to hasten the formation of a harder, rideable surface. Nevertheless, most individuals were clear about the potential hazards of poor water 'management':

Water is the scourge of trail builders. It gets built up and gets places and completely changes the trail ... When you get that massive power of nature and that raging torrent of water it can just cut through terrain and wash things away, which makes the trail really sketchy for the riders (Paul)

The snow gets on it (plant life) and it collapses onto the trail. It collects all the brambles so the brambles grow up into it. They grow over the top and come into the trails. So, you get lacerated by brambles at eye height. So, you have to manage it - all the time it's managed (John)

However, for Andy this was part of the fun:

It's funny, on Sunday I did some digging at X woods and the trails were running amazing ... Then on Monday I went after work and did the same thing but it drizzled a bit and it was a completely different kettle of fish - the characteristics of the trail were very different. That's a big part of the fun, dealing with how much it changes.

These accounts provide a number of insights into the dangers associated with Nature sports, and the risk work that is undertaken by various individuals to prepare for, and manage such dangers (Beames and Pike 2008). Trail builders evince varying levels of risk alignment and aversion, and their orientation in this regard is central to their performance of a (social) identity. Of particular interest here is the way that these risks are managed in the presence of the 'big other' (Žižek 2006); that is, an unwritten constitution that hovers above these social interactions but can never be directly grasped or envisaged. Indeed, the trail builders have to manage their risks using a symbolic order (i.e. the movement of mountain bikes and the intentions of future riders), which takes place against the backdrop of the 'Real' (i.e. Nature, Water). The result of this is an ethic of cultivation (involving humans and nonhumans) that is 'grounded in the contingency of care for this world' (Connolly 2013: 401). Through the management of water and its manifold affects, the participants are forced to make 'situational judgements about how to enact that care in a world in which surprising changes periodically emerge’ (Connolly 2013: 401). 
The upshot of this paranoid sensibility is that water is positioned as a 'Hyperobject'; 'a bundle of entities massively distributed in time and space that ... it is impossible for humans to see or touch directly' (Morton 2017: 40). In this regard it is worth quoting Robert at length, as he provides perhaps the most articulate overview of how this orientation might emerge:

People need to bear in mind that if you are going to build on a bigger scale like at $\mathrm{X}$ (location), there were lots of mines there. The pond there was where the miners used to wash. If you start altering the drainage on the hillside you are going to have a hell of a lot more water than hits the pond and then very likely wash away the ancient dam which it flow over the top of. That then goes underneath the road into a second pond and then that pond is controlled by a slew scape that flows down into another pond ... Then different types of trees go in - some of which drink more and others don't so certain areas go soggy. Then there is felling because of disease where they have to take out acres of it, so you'll have more and more water coming off the hill, but those little dams were never designed to take it all. So, drainage is hugely important because if it's not done properly it can alter parts of the ecosystem.

Through his management of water erosion within a specific mountain bike trail centre, Robert has been connected to an infinite regress of planetary considerations, which range in scale from the local (ponds, trees) to the regional (dams, hillsides, mining) and the global (tree felling industry, ecosystems). The more he and his colleagues dig at this site, the more they come to realize the impact that the smallest act (i.e. digging in the soil and removing local plant life) can have on a larger scale. At the same time, every one of these global considerations seems to be 'subscended' by their parts; that is, bigger than they first appear (Morton 2013). Water also becomes a conduit for 'temporal undulation' (2013: 55); through which objects such as trees, dams, drains and spades 'entangle one another in a crisscrossing mesh of space time fluctuations' (2013: 65). 100-year-old mines and 'ancient dams' are all 'present' in the composition of the soil and the hillside's capacity for drainage, and each affect becomes enfolded within a present-time here and now that is encountered in the trail builders' labour. Water, as hyperobject, contributes to the trail builders' sense of paranoia, in that it reveals both the inherent weakness of their built-up features and the fragility of the material, spatial, temporal and (non) social arrangements upon which those features depend.

\section{Conclusion}

By examining the trail building assemblage, this article has provided a critical analysis of how trail builders interact in and with the 'natural' environment. With regard to the work of Morton (2007, 2013, 2016, 2017, 2018), we have detailed how trail builders display an ecological awareness which accentuates the ambiguity of nature and, more importantly, how such ambiguity resides within the merging interactions between the human and the non-human. This ambiguity was identified in two overarching findings: 1) nature as spectre and 2) the material vibrancy of water. Together, these findings 
highlight an awareness of ecology that is constitutive of the pleasures of being; indeed, a pleasure formed from the ambiguity, or 'strangeness' (Morton 2017) of being in and with nature. This posits an awareness of nature that is not reverent or exploitative, but instead, enveloped in the understanding that one's actions are interdependently related to the leisure experience itself.

Perhaps the most significant conclusion that can be drawn from these findings with regard to leisure in nature is that trail builders do not consciously position themselves as ecological subjects. Yet their praxis reveals that they are already acting ecologically, without the need to identify as such (Morton 2018). By digging, sculpting, lifting and re-purposing non-human 'matter' and working alongside nonhuman organisms (smelly boar and inquisitive deer) the participants are able to tune to the dynamic and effervescent qualities of the symbiotic real. By either enabling (i.e malleable dirt) or constraining (i.e shale-filled dirt) human agency these organisms and materials reveal a variety of humannonhuman interdependencies that are part of a living, dynamic relation. 'Tuning' to the symbiotic real is continued in the ongoing 'battle' that the trail builders maintain with water. Indeed, in their often futile battle to lessen or 'manage' the effects of water on a trail, the participants are reminded of Nature's destructive power as well as the ambiguous, animate and spectral canvas upon which their trails are rendered and enacted.

We believe that such awareness of Nature's non-neutrality, induces a sense of ambiguity that defers from any resignation by inducing a strange sense of temporality, from which 'ethical demand issues from a future that is radically unknown and unknowable' (Skrimshire 2018: 16). Morton (2018: 131) refers to this temporal moment as an experiential 'nowness', in which 'the present moment collapses and I'm left with an uncertain, spectral futurality'. In this moment, one might argue, the trail builders sit at the precipice of creation (of tangible trail features) and destruction (water erosion), but it is in this uncertain, melancholic space that solidarity with nonhumans emerges and an uncertain, but radically different future unfolds. Skrimshire (2018) refers to Morton's (2013) 'strange stranger' to highlight the ambiguity and unknownness of current ethical decisions on the future. Here, 'One cannot even be certain that the very terms of our ethical deliberations - whether rights, duties, or virtues - make sense in the strangeness of the far future' (Skrimshire 2018: 16).

Set against this ecological (un)awareness, we believe it necessary to re-orient understandings of the Anthropocene to recognize the ambivalent role played by the 'Anthropos' in environmental considerations of leisure, work, conservation and tourism, amongst others. Indeed, given the insights provided in this paper, it would appear that the landscapes we inhabit are not governed by and subject to the ruling hand of human reason, as the term would suggest, but can also be consequences of the "the unintended effects of collective human labor (Wark 2015b [italics in original]) and the uncertainty of the future. As such, it is also important to consider the ways in which matter, and by extension 'Nature', might resist and prevent human incorporation. Thinking of the Anthropocene in this way demands a decidedly political approach to conceiving the human and non-human which considers both the intended and unintended consequences of the Anthropocene. In addition: 
Rather than being the end point of the analyses, an assessment of human/ environment assemblages must be the start of a new way of thinking...about nature and culture, with practical implications for how we research social and natural worlds, but also for how - ethically - sociology engages with the nonhuman (Fox and Alldred 2018: 44)

In committing to this outcome it is crucial that we continue to question the depoliticization of the nonhuman marked by empty liberal signifiers such as 'Nature' or 'sustainability' whilst reimagining how we might approach a range of emergent material relationalities and environmental dilemmas within a range of global and neo-liberal leisure forms. While not over-stating the significance of our findings, we believe that the responses provided by the trail builders in this study reveal one such political re-thinking that can serve to promote a form of ecological awareness which does not embellish nature's 'natural' significance, but instead, orientates our acknowledgement of and, place within, the ambiguity of the Anthropocene.

\section{Compliance with Ethical Standards}

\section{Conflict of Interest None.}

Open Access This article is distributed under the terms of the Creative Commons Attribution 4.0 International License (http://creativecommons.org/licenses/by/4.0/), which permits unrestricted use, distribution, and reproduction in any medium, provided you give appropriate credit to the original author(s) and the source, provide a link to the Creative Commons license, and indicate if changes were made.

\section{References}

Acton, L., Campbell, L., Clery, J., Gray, N., \& Halpin, P. (2019). What is the Sargasso Sea? The problem of fixing space in a Fluid Ocean. Political Geography, 68, 86-100.

Bakker, K. (2004). An uncooperative commodity: Privatizing water in England and Wales. Oxford: Oxford University Press.

Beames, S., \& Pike, E. (2008). Goffman Goes rock climbing: Using creative fiction to explore the presentation of self in outdoor education. Australian Journal of Outdoor Education, 12(2), 3-11.

Bennett, J. (2004). The force of things: Steps toward an ecology of matter. Political Theory, 32(3), 347-372.

Bennett, J. (2010). Vibrant matter: A political ecology of things. Durham: Duke University Press.

Braidotti, R. (2013). The Posthuman. Cambridge: Polity.

Braun, B. (2015). New materialisms and neo-Liberal natures. Antipode, 47(1), 1-14.

Brewer, J., \& Sparkes, A. (2011). The meanings of outdoor physical activity for parentally bereaved young people in the United Kingdom: Insights from an ethnographic study. Journal of Adventure Education and Outdoor Learning, 11(2), 127-143.

Brown, K. (2012). Sharing public spaces across difference: Attunement and the contested burdens of choreographing the encounter. Social and Cultural Geography, 13(7), 801-820.

Brown, K. (2014). Spaces of play, spaces of responsibility: Creating dichotmous geographies of outdoor citizenship. Geoforum, 55, 22-32.

Brown, M. K., Dilley, R., \& Marshall, K. (2008). Using a head - Mounted video camera to understand social worlds and experiences. Sociological Research Online, 13(6).

Brymer, E. (2009). Extreme sports as a facilitator of ecocentricity and positive lifestyle changes. World Leisure Journal., 51(1), 47-53. 
Brymer, E., \& Gray, T. (2009). Dancing with nature: Rhythm and harmony in extreme sport participation. Journal of Adventure Education \& Outdoor Learning, 9(2), 135-149.

Campbell, N., Dunne, S., \& Ennis, P. (2019). Graham Harman, immaterialism: Objects and social theory. Theory, Culture and Society, 36(3), 121-137.

Church, A., \& Ravenscroft, N. (2011). Politics, research and the natural environment: The lifeworlds of waterbased sport and recreation in Wales. Leisure Studies., 30(4), 383-386.

Collins, M. (2011). The politics of the environment, and noisy sports: Two totally different outcomes in the Lake District National Park for powerboating and off-road motoring. Leisure Studies, 30(4), 423-452.

Connolly, W. (2013). The 'new materialism' and the fragility of things. Millenium, 41(3), 399-412.

Coon, J. T., Boddy, K., Stein, K., Whear, R., Barton, J., \& Depledge, M. H. (2011). Does participating in physical activity in outdoor natural environments have a greater effect on physical and mental wellbeing than physical activity indoors? A systematic review. Journal of Epidemiology and Community Health, $65(2), 1-40$.

Creyer, E. H., Ross, W. T., \& Evers, D. (2003). Risky recreation: An exploration of factors influencing the Likelyhood of participation and the effects of experience. Leisure Studies, 22, 239-253.

Dalby, S. (2013). The geopolitics of climate change. Political Geography, 37, 38-47.

Dashper, K. (2019). Moving beyond anthropocentrism in leisure research: Multispecies perspectives. Annals of Leisure Research., 22(2), 133-139.

David, M., \& Sutton, C. (2011). Social research: An introduction. Oxford: Sage.

Deleuze, G., \& Guattari, F. (1987). A thousand plateaus: Capitalism and schizophrenia. Minneapolis: University of Minnesota Press.

Fox, N., \& Alldred, P. (2018). New materialism. In P. A. Atkinson (Ed.), The Sage encyclopedia of research methods (pp. 35-42). London: Sage.

Fullagar, S. (2017). Post-qualitative inquiry and the new materialist turn: Implications for sport, health and physical culture research. Qualitative Research in Sport, Exercise and Health, 9(2), 247-257.

Gibbs, D., \& Holloway, L. (2018). From experience economy to experience landscape: The example of UK trail centres. AREA, 50(2), 248-255.

Harman, G. (2009). Prince of networks: Bruno Latour and metaphysics. Melbourne: re.press.

Harman, G. (2012). The well-wrought hammer: Object-oriented literary criticism. New Literary History, 43(2), 183-203.

Harman, G. (2016). Immaterialism: Objects and social theory. London: Polity Press.

Harvey, P., \& Knox, H. (2014). Objects and materials: An introduction. In: Harvey, P., Casella, E., Evans, G., Knox H., McLean, C., Silva, B., Thoburn, N., \& Woodward, K. (Eds.), (pp. 1-18). Objects and materials: A Routledge companion. London: Routledge.

Heer, C., Rusterholz, H. P., \& Baur, B. (2003). Forest perception and knowledge of hikers and mountain bikers in two different areas in northwestern Switzerland. Environmental Management, 31(6), 709-723.

Helle, N., \& Lyhne, I. (2016). Adding action to the interview: Conceptualizing an interview approach inspired by action research elements. Action Research, 14(1), 54-71.

HMSO. (2011). The Natural Choice: Securing the Value of Nature, White Paper. Retrieved from https://assets. publishing.service.gov.uk/government/uploads/system/uploads/attachme nt_data/file/228842/8082.pdf

Howe, P. D., \& Morris, C. (2009). An exploration of the co-production of performance running bodies and natures within 'running Taskscapes'. Journal of Sport \& Social Issues, 33(3), 308-330.

Humberstone, B. (2011). Embodiment and social and environmental action in nature-based sport: Spiritual spaces. Leisure Studies, 30(4), 495-512.

Ingold, T. (2000). The perception of the environment: Essays on livelihood, dwelling and skill. London: Routledge.

Jim Cherrington, Jack Black, Nicholas Tiller, (2018) Running away from the taskscape: ultramarathon as 'dark ecology'. Annals of Leisure Research:1-21.

Kopnina, H. (2014). Unsettling anthropocentrism. Dialectical Anthropology, 38, 387-396.

Kopnina, H., Washington, H., Taylor, B., \& Piccolo, J. (2018). Anthropocentrism: More than just a misunderstood problem. Journal of Environmental Ethics, 31, 109-127.

Krein, K. J. (2014). Nature sports. Journal of the Philosophy of Sport, 41(2), 193-208.

Kuby, C. (2017). Why a paradigm shift of 'more than human ontologies' is needed: Putting to work poststructural and posthuman theories in writers' studio. International Journal of Qualitative Studies in Education, 30(9), 877-896.

Latour, B. (1993). We Have Never Been Modern. Cambridge: Harvard University Press.

Latour, B. (1996). On actor-network theory: A few clarifications plus more than a few complications. Danish Philosophy Journal, 25(3-4), 47-64. 
Latour, B. (1999). On recalling ANT. In J. Law \& J. Hassard (Eds.), Actor network theory and after (pp. 1526). Oxford: Blackwell.

Latour, B. (2004). How to talk about the body? The normative dimension of science studies. Body and Society, $10(2-3), 205-229$.

Latour, B. (2005). Reassembling the social: An introduction to actor-network theory. Oxford: Oxford University Press.

Leder, D. (1990). The absent body. Chicago: University of Chicago Press.

Leledaki, A., \& Collinson, J. K. (2015). Sensing the outdoors: A visual and haptic phenomenology of outdoor exercise embodiment. Leisure Studies, 34(4), 457-470.

Lemke, T. (2017). Materialism without matter: The recurrence of subjectivism in object-oriented ontology. Diskinction: Journal of Social Theory., 18(2), 133-152.

Lorimer, J. (2008). Nonhuman Charisma. Environment and Planning: Society and Space, 25, 911-932.

Macnaghten, P., \& Urry, J. (1998). Contested natures. In London; thousand oaks. Calif: SAGE Publications.

Mansfield, L. (2009). Fitness cultures and environmental (in)justice? International Review for the Sociology of Sport, 44(4), 345-362.

Mansfield, B. (2018). From the commons to the body to the planet: Neoliberalism/materiality/socionatures. Environment and Planning E: Nature and Space, 1(1-2), 34-38.

Mansfield, L., \& Wheaton, B. (2011). Guest editorial: Leisure and the politics of the environment. Leisure Studies, 30(4), 383-386.

Markula, P. (2018). What is new about new materialism for sport sociology? Reflections on body, movement, and culture. Sociology of Sport Journal, 36(1), 1-11.

Marston, S., Jones, J. P., \& Woodward, K. (2005). Human geography without scale. Transactions of the Institute of British Geographers, 30, 416-432.

Michael, M. (2000). Reconnecting culture, technology and nature: From society to heterogeneity. London: Routledge.

Michael, M. (2001). These boots are made for walking... mundane technology the body and humanenvironment relations. In P. Magnaten \& J. Urry (Eds.), Bodies of nature (pp. 107-127). London: Sage.

Monforte, J. (2018). What is in new materialism for a newcomer? Qualitative Research in Sport. Exercise and Health, 10(3), 378-390.

Monforte, J., Perez-Samaniego, V., \& Smith, B. (2018). Travelling material $\leftrightarrow$ semiotic environments of disability, rehabilitation, and physical activity. Qualitative Health Research [online first], https://doi. org/10.1177/1049732318820520.

Moore, J. W. (2015). Capitalism in the web of life: Ecology and the accumulation of capital. New York: Verso.

Morton, T. (2007). Ecology without nature. London: Harvard University Press.

Morton, T. (2013). Hyperobjects: Philosophy and ecology after the end of the world. Minneapolis: University of Minnesota Press.

Morton, T. (2016). Dark ecology: For a logic of future coexistence. New York: Columbia University Press.

Morton, T. (2017). Humankind: Solidarity with nonhuman people. In London. New York: Verso.

Morton, T. (2018). Being ecological. Cambridge: MIT Press.

Naes, A. (1972). Shallow and the deep. Long-range ecology movements: A summary. Inquiry, 16(1), 95-100.

Panelli, R. (2010). More-than-human social geographies: Posthuman and other possibilities. Progress in Human Geography, 34(1), 79-87.

Perkins, H. (2008). Ecologies of actor-networks and (non) social labour within urban political economies of nature. Geoforum, 38(6), 1152-1162.

Pretty, J., Peacock, J., Sellens, M., South, N., \& Griffin, M. (2007). Green exercise in the UK countryside: Effects on health and psychological well-being, and implications for policy and planning. Journal of Environmental Planning and Management, 50(2), 211-231.

Purdy, J. (2015). After nature: A politics for the Anthropocene. Cambridge: Harvard University Press, London.

Riessman, C. (2008). Narrative methods for the human sciences. London: Sage.

Rocheleau, D., \& Roth, R. (2007). Rooted networks, relational webs and powers of connection: Re-thinking human and political ecologies. Geoforum, 38, 433-437.

Rubin, H., \& Rubin, I. (2011). Qualitative interviewing: The art of hearing data. London: Sage.

Saldana, J. (2011). Fundamentals of qualitative research. Oxford: Oxford University Press.

Shoreman-Ouimet, E., \& Kopnina, H. (2016). Culture and conservation: Beyond anthropocentrism. In London. New York: Routledge.

Skrimshire, S. (2018). Deep Time and Secular Time: A Critique of the Environmental 'Long View'. Theory, Culture \& Society. [online first]. https://doi.org/10.1177/0263276418777307

Snaza, N., Sonu, D., Truman, S. E., \& Zaliwska, Z. (2016). Pedagogical matters: New materialism and curriculum studies. New York: Peter Lang. 
Stevens, P. (2012). Towards an Ecosociology. Sociology., 46(4), 579-595.

Taylor, A. (2009). Slavoj Zizek: Ecology. In A. Taylor (Ed.), Examined life: Excursions with contemporary thinkers (pp. 155-184). New York: The New York Press.

Thompson, R. (2018). Gardening for health: A regular dose of gardening. Clinical Medicine, 3(18), 201-205.

Toma, J. D. (2000). How getting close to your participants makes your data better. Theory into Practice., 39(3), 177-184.

Wark, M. (2015a). Molecular red: Theory for the Anthropocene. London: Verso.

Wark, M. (2015b). Zizek and Me. Public Seminar. http://www.publicseminar.org/2015/06/zizek-and-me/ 4 June 2015.

Weedon, G. (2015). Camaraderie reincorporated: Tough Mudder and the extended distribution of the social. Journal of Sport and Social Issues, 39(6), 431-454.

White, D., Rudy, A. P., \& Gareau, B. J. (2016). Environments, natures and social theory. London: Palgrave Macmillan.

Yeh, H. P., Stone, J. A., Churchill, S. M., Wheat, J. S., Brymer, E., \& Davids, K. (2016). Physical, psychological and emotional benefits of green physical activity: An ecological dynamics perspective. Sports Medicine, 46(7), 947-953.

Žižek, S. (2006). How to read Lacan. London: Granta Books.

Publisher's Note Springer Nature remains neutral with regard to jurisdictional claims in published maps and institutional affiliations. 